\title{
Design and Synthesis of Metallopeptide Sensors: Tuning Selectivity with Ligand Variation
}

\author{
Joung-Min Kim, Bishnu Prasad Joshi, and Keun-Hyeung Lee*
}

\author{
Bioorganic Chemistry Lab, Department of Chemistry, Inha University, Incheon 402-751, Korea. *E-mail: leekh@inha.ac.kr \\ Received July 6, 2010, Accepted July 19, 2010
}

\begin{abstract}
We chose a fluorescent pentapeptide sensor (-CPGHE) containing a dansyl fluorophore as a model peptide and investigated whether the selectivity and sensitivity of the peptides for heavy and transition metal ions could be tuned by changing amino acid sequence. In this process, we developed a selective peptide sensor, Cp1-d (-HHPGE, $\mathrm{K}_{\mathrm{d}}=$ $670 \mathrm{nM}$ ) for detection of $\mathrm{Zn}^{2+}$ in $100 \%$ aqueous solution and a selective and sensitive peptide sensor, Cp1-e $\left(-\mathrm{CCHPGE}, \mathrm{K}_{\mathrm{d}}=24 \mathrm{nM}\right.$ ) for detection of $\mathrm{Cd}^{2+}$ in $100 \%$ aqueous solution. Overall results indicate that the selectivity and sensitivity of the metallopeptide sensors to specific heavy and transition metal ions can be tuned by changing amino acid sequence.
\end{abstract}

Key Words: Peptides, $\mathrm{Zn}^{2+}, \mathrm{Cd}^{2+}$, Peptide sensor, Chemical sensor

\section{Introduction}

Many metalloproteins that was complexed with heavy and transition metal ions are essential in various types of biological processes. ${ }^{1-2}$ Design of biopolymers provides the bioinorganic chemist a powerful tool toward the goal of addressing interesting questions. For example, how is metal-binding affinity of proteins and peptides tuned by primary amino acid sequences? How does the structural context of a metal binding site of the biopolymers affect metal binding ability?

Previously, we reported that a small peptide sensor (Cp1) that mimicked the zinc binding sites of metalloproteins. ${ }^{3}$ The peptide sensor containing His, Glu, and Cys residues as a ligand showed a turn on response to the specific transition metal ions $\left(\mathrm{Zn}^{2+}\right.$ and $\left.\mathrm{Cd}^{2+}\right)$ in $100 \%$ aqueous solution. Furthermore, we synthesized several peptide sensors that had different secondary structures and found out that metal-binding affinity of the peptide sensors could be tuned by specific secondary structures. ${ }^{4,5}$

In the present study, we investigated whether or not metalbinding affinity of the small peptide sensors could be tuned by modulating amino acid sequence. To investigate the role of amino acids for selective monitoring of $\mathrm{Zn}^{2+}$ ions, we chose $\mathbf{C p 1}$ (-CPGHE) as a model peptide and synthesized several peptide sensors, as shown in Table 1. We measured the emission spectra of the peptide sensors in the presence of various metal ions in HEPES buffer solution at $\mathrm{pH}$ 7.4. Overall results indicated that the position of the amino acids (His, Cys and Glu) in the peptide moiety in the sensors plays an important role in the binding affinity to specific metal ions rather than the selectivity to various metal ions. Furthermore, we confirmed the selectivity and sensitivity of the peptide sensors for heavy and transition metal ions could be tuned by changing amino acids. Cp1-d (-HHPGE) among the peptide series showed the great selectivity for $\mathrm{Zn}^{2+}$ over $\mathrm{Cd}^{2+}$. Specially, Cp1-e (-CCHPGE) unlike the other peptide sensors shows more potent binding affinity to $\mathrm{Cd}^{2+}$ than $\mathrm{Zn}^{2+}$ ions.

\section{Results and Discussion}

The peptide sensors (Cp1-a to $\mathbf{C p 1 - c ) ~ w e r e ~ s y n t h e s i z e d ~ t o ~}$

elucidate the relationship between the metal binding affinity and the position of specific amino acids (His, Cys, and Glu). As a pre-organization of the ligand site of the peptides is required for the selective monitoring of metal ions, ${ }^{3,5}$ all peptide sensors employed in this study commonly contained Pro-Gly amino acids to have pre-organized structure. ${ }^{6}$ As shown in Scheme 1, 1,5-dimethylaminonaphthalene sulfonamide (dansyl) group as a fluorophore was introduced to the N-terminal of the peptides because the dansyl group can display a large Stokes shift along with varying quantum yield by changing its local environment and the dansyl fluorophore of various chemical sensors has been used to effectively detect metal ions by chelation enhanced fluorescence $(\mathrm{CHEF})$ effect. $^{7}$

We synthesized three peptides consisting of the same amino acid compositions (Cys, Pro, Gly, His, and Glu), as shown in Table 1. Cp1-d containing two His residues and Glu as a ligand

Dansyl-His-Pro-Gly-Cys-Glu-NH 2 Cp1-a

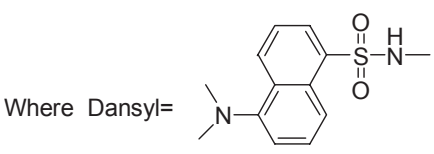

Scheme 1. Chemical structures of representative peptide sensors

Table 1. Sequences, mass, and retention time of peptide sensors

\begin{tabular}{ccccc}
\hline S. No. Name & Sequence & $\begin{array}{c}\text { Cal. Mass/ } \\
\text { Obs. Mass } \\
\left(\mathrm{M}+\mathrm{H}^{+}\right)\end{array}$ & $\begin{array}{c}\text { Retention } \\
\text { time } \\
(\mathrm{min} .)\end{array}$ \\
\hline 1 & Cp1-a & Dansyl-HPGCE-NH 2 & $773.26 / 773.97$ & 23.85 \\
2 & Cp1-b & Dansyl-CHPGE-NH $_{2}$ & $773.26 / 773.95$ & 24.05 \\
3 & Cp1-c & Dansyl-EPGCH-NH 2 & $773.26 / 773.84$ & 23.08 \\
4 & Cp1-d & Dansyl-HHPGE-NH & $807.25 / 807.95$ & 14.57 \\
5 & Cp1-e & Dansyl-CCHPGE-NH & $876.20 / 876.91$ & 18.55
\end{tabular}

Solvent A was water containing $0.1 \%(\mathrm{v} / \mathrm{v})$ TFA and solvent B was acetonitrile containing $0.1 \%(\mathrm{v} / \mathrm{v})$ TFA. The peptides were analyzed with a linear gradient of $5-50 \% \mathrm{~B}$ over $45 \mathrm{~min}$. 


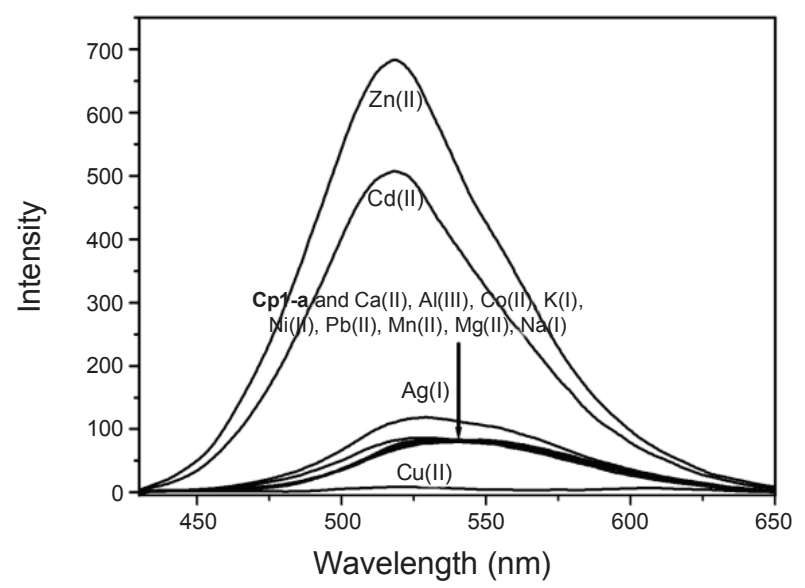

Figure 1. Fluorescence spectra of Cp1-a $(5 \mu \mathrm{M})$ in $10 \mathrm{mM}$ HEPES buffer solution $(\mathrm{pH}=7.4)$ in the presence of various metal ions (1 equiv).

was synthesized because His is frequently found as a ligand in metal binding site of several metalloproteins. We synthesized Cp1-e in which one more Cys residue was appended in the peptide moiety of Cp1-e. The peptide sensors were synthesized in solid-phase peptide synthesis with Fmoc chemistry. ${ }^{8}$ After cleavage of the crude product from resin, each peptide was purified using semi-preparative HPLC with a $\mathrm{C}_{18}$ column. The successful synthesis and purity (>95\%) were confirmed by analytical HPLC with a $\mathrm{C}_{18}$ column and an ESI mass spectrometer.

As the peptides are fully water soluble, the fluorescence spectrum of the peptides was measured in $100 \%$ aqueous media. Fluorescence spectra ranging from 350 to $650 \mathrm{~nm}$ were recorded with excitation at a wavelength of $330 \mathrm{~nm}$. To investigate metal selectivity of the peptides, we measured the fluorescence spectrum of the peptides in the presence of various metal cations $\left(\mathrm{Ca}^{2+}, \mathrm{Cd}^{2+}, \mathrm{Co}^{2+}, \mathrm{Pb}^{2+}, \mathrm{Cu}^{2+}, \mathrm{Ag}^{+}, \mathrm{Mg}^{2+}, \mathrm{Mn}^{2+}, \mathrm{Ni}^{2+}, \mathrm{Zn}^{2+}\right.$ as perchlorate anion and $\mathrm{Na}^{+}, \mathrm{Al}^{3+}, \mathrm{K}^{+}$, as chloride anion). Figure 1 shows fluorescent emission spectra of Cp1-a $(5 \mu \mathrm{M})$ in $10 \mathrm{mM}$ HEPES buffer solution at $\mathrm{pH} 7.4$ containing each metal ion (1 equiv).

Cp1-a like Cp1 shows a considerable response with $\mathrm{Zn}^{2+}$, $\mathrm{Cd}^{2+}$, and $\mathrm{Cu}^{2+}$. The emission intensity at $515 \mathrm{~nm}$ increased in the presence of $\mathrm{Zn}^{2+}$ and $\mathrm{Cd}^{2+}$, whereas the emission intensity at $515 \mathrm{~nm}$ decreased in the presence of $\mathrm{Cu}^{2+}$. Figure 2 shows emission intensity change of Cp1-a, Cp1-b and Cp1-c in $10 \mathrm{mM}$ HEPES buffer solution at $\mathrm{pH} 7.4$ containing each metal ion (1 equiv). Cp1-b and Cp1-c also exhibited turn on response to $\mathrm{Zn}^{2+}$ and $\mathrm{Cd}^{2+}$, but showed turn off response to $\mathrm{Cu}^{2+}$.

This result indicates that the position of Cys, His, and Glu in the peptide moiety of the peptide sensors did not play a critical role in the selectivity for $\mathrm{Zn}^{2+}, \mathrm{Cd}^{2+}$, and $\mathrm{Cu}^{2+}$. Generally, chemical or peptide sensors are rarely able to differentiate between $\mathrm{Zn}^{2+}$ and $\mathrm{Cd}^{2+}$ due to the similar size and the same positive charge. ${ }^{9}$ However, the sensitivity for specific metal ions seemed to depend on the position of the amino acid of the peptide sensors. Cp1-a and Cp1-b like $\mathbf{C p 1}$ showed more sensitive response to $\mathrm{Zn}^{2+}$ than $\mathrm{Cd}^{2+}$, whereas $\mathbf{C p 1 - c}$ exhibited similar response to $\mathrm{Zn}^{2+}$ and $\mathrm{Cd}^{2+}$, as shown in Figure 2 .

Emission spectra of Cp1-d(-HHPGE) were measured in the presence of various metal ions, as shown in Figure 3. Interestingly, Cp1-d containing two His residue and a Glu residue as a ligand exhibited a great selectivity for $\mathrm{Zn}^{2+}$ over $\mathrm{Cd}^{2+}$ in comparison to the other peptides (Cp1, Cp1-a, Cp1-b, and $\mathbf{C p 1 - c ) . ~}$ Considering the fact that almost all chemical sensors suffer from the selectivity between $\mathrm{Zn}^{2+}$ and $\mathrm{Cd}^{2+}$, this result shows important information for the design of chemical sensors that have a great selectivity for $\mathrm{Zn}^{2+}$ over $\mathrm{Cd}^{2+}$. The result strongly suggests that a Cys residue as a soft ligand plays an important role in the selective and sensitive response of the peptides to $\mathrm{Cd}^{2+}$ due to the more softness of $\mathrm{Cd}^{2+}$ than $\mathrm{Zn}^{2+}$. To confirm this suggestion, we synthesized Cp1-e (-CCHPGE) containing two Cys residues, His and Glu as a ligand and measured emission spectra in the presence of various metal ions. As we expected, Cp1-e shows more sensitive response to $\mathrm{Cd}^{2+}$ than $\mathrm{Zn}^{2+}$. Overall results revealed that the selectivity and sensitivity of the metallopeptides to specific heavy and transition metal ions can be tuned by changing amino acid sequence.

The previous reported peptide sensors containing a His residue showed a turn off response to $\mathrm{Cu}^{2+}$ because GlyGlyHis and GlyHis are general peptide motifs originated from the amino terminal $\mathrm{Cu}^{2+}$ and $\mathrm{Ni}^{+}$binding (ATCUN) site. ${ }^{10}$ Thus, it is not surprising that all peptide sensors containing at least one His residue employed in this study showed a turn off response to $\mathrm{Cu}^{2+} \cdot \mathrm{Cu}^{2+}$ as a paramagnetic metal ion quenches fluorescence emission. ${ }^{11} \mathbf{C p 1 - d}$ and $\mathbf{C p 1 - e}$ among the peptide series, shows most sensitive response to $\mathrm{Cu}^{2+}$. This can be explained by the
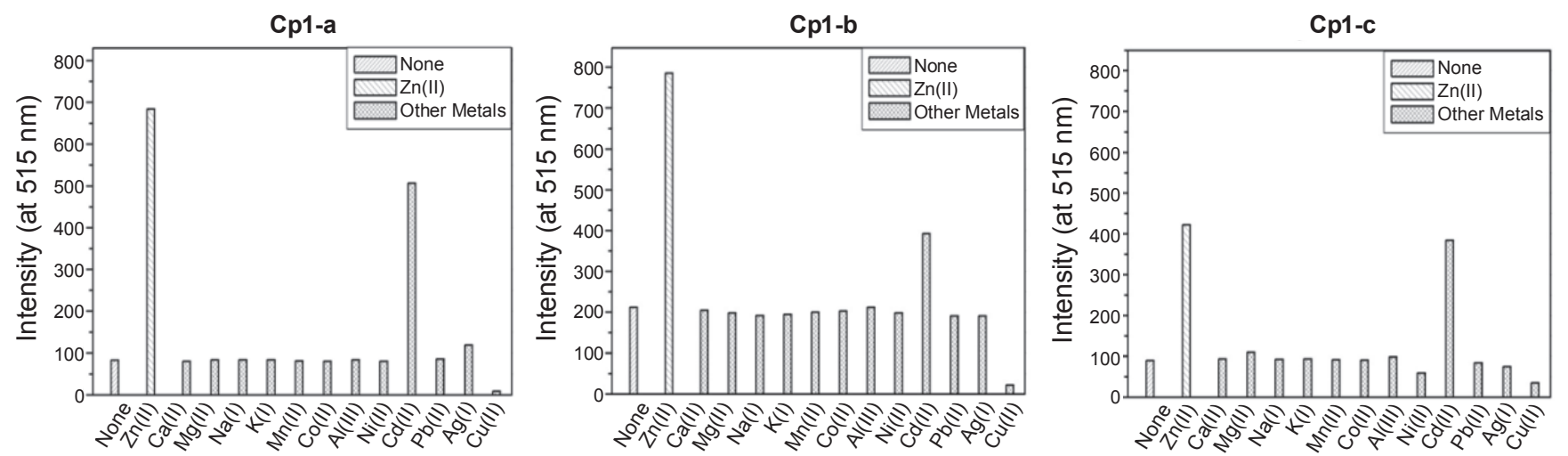

Figure 2. Emission intensity $\left(\mathrm{I}_{515 \mathrm{~nm}}\right)$ change of peptide sensors $(5 \mu \mathrm{M})$ in the presence and absence of various metal ions $(1$ equiv) in $10 \mathrm{mM}$ HEPES buffer solution $(\mathrm{pH} 7.4), \lambda_{\mathrm{ex}}=330 \mathrm{~nm}$. 

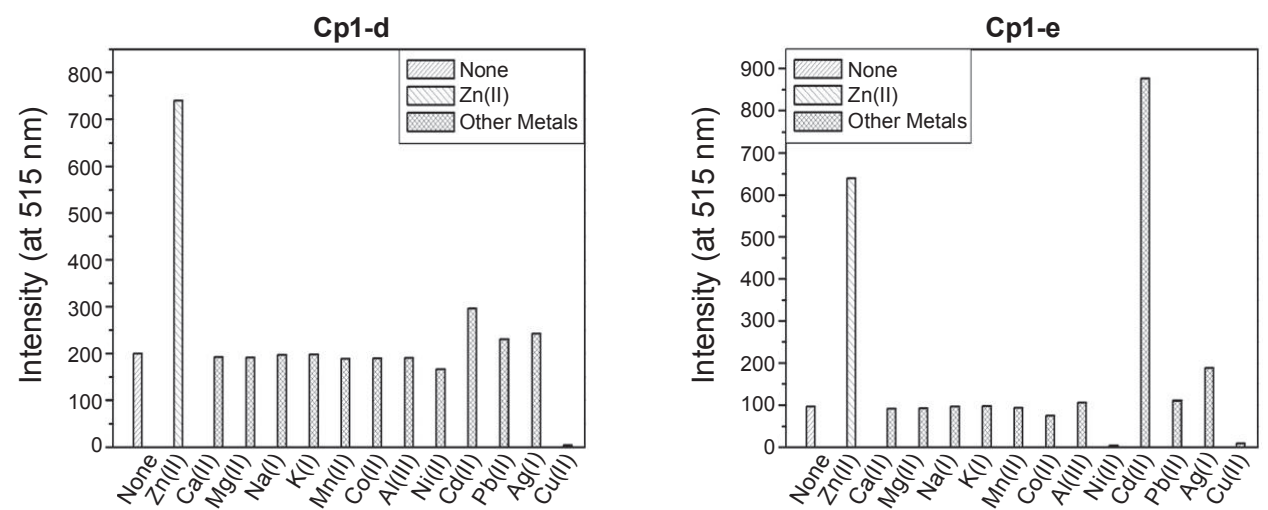

Figure 3. Emission intensity $\left(\mathrm{I}_{515 \mathrm{~nm}}\right)$ change of peptide sensors $(5 \mu \mathrm{M})$ in the presence and absence of various metal ions $(1$ equiv) in $10 \mathrm{mM}$ HEPES buffer solution $(\mathrm{pH} 7.4), \lambda_{\mathrm{ex}}=330 \mathrm{~nm}$.
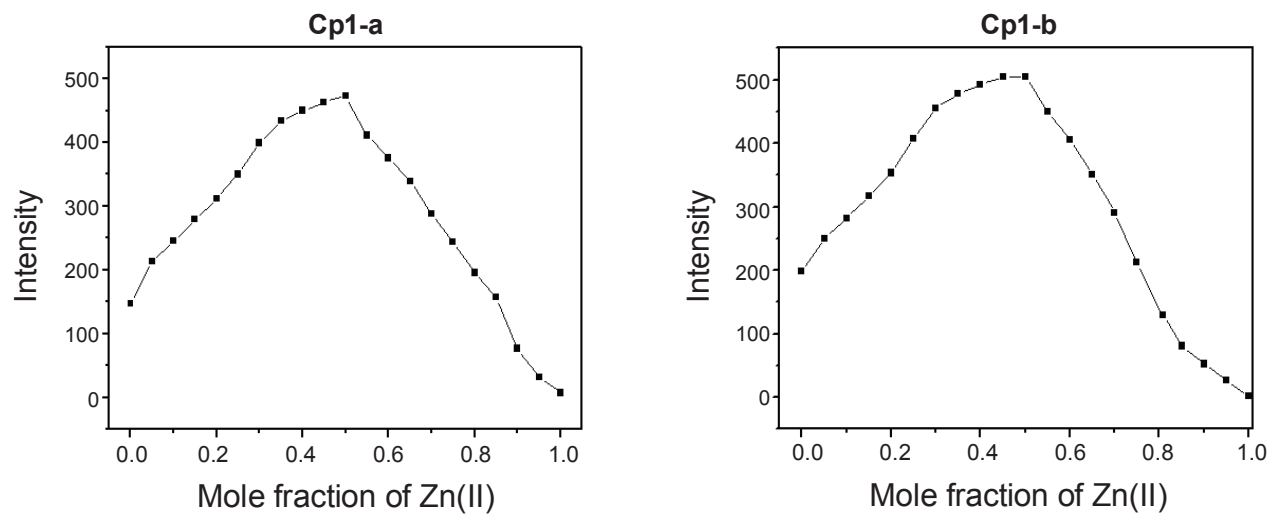

Figure 4. A Job plot for the representative peptides. The total concentration of peptide and $\mathrm{Zn}^{2+}$ is $2.5 \mu \mathrm{M}$.

fact that Cp1-d contained two His residues and Cp1-e contained His residues as well as two Cys residues for interaction with $\mathrm{Cu}^{2+}$.

We measured the binding affinities of the peptides for $\mathrm{Zn}^{2+}$ because the model peptide, $\mathbf{C p 1}$ displayed a great sensitivity for $\mathrm{Zn}^{2+}$ and zinc ions play an important role in biological functions, such as gene expression, apoptosis, enzyme regulation, and amyloid fibril formation. ${ }^{12}$ Previous reported $\mathbf{C p} \mathbf{1}$ formed a 1:1 complex in the interaction with $\mathrm{Zn}^{2+}$ and $\mathrm{Cd}^{2+}$, respectively on the basis of Job's plot analysis. Thus, we did Job's plot analysis of the peptide sensors. As shown in Figure 4, the

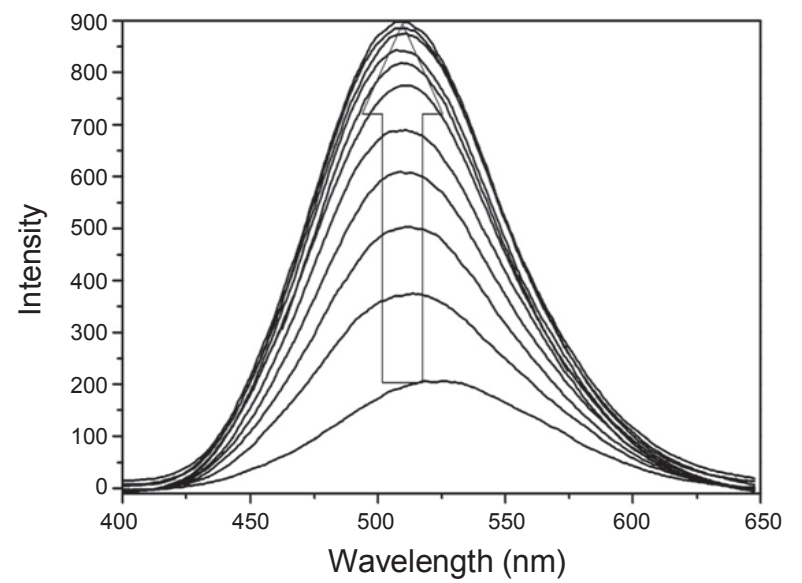

emission intensity of the complex between the peptides and $\mathrm{Zn}^{2+}$ exhibits a maximum at $0.5 \mathrm{~mol}$ fraction, which supports that the peptides form 1:1complex with $\mathrm{Zn}^{2+}$.

In addition, nonlinear least-squares fitting of the titration profiles based on the 1:1 binding model strongly supports that the peptide sensors forms 1:1 complex with $\mathrm{Zn}^{2+}$. The dissociation constant of the peptide sensors was calculated based on the titration curve with $\mathrm{Zn}^{2+}$ by non-linear least square fitting. Assuming 1:1 complex formation, the dissociation constant was calculated based on the titration curve with $\mathrm{Zn}^{2+}$ by non-linear least square fitting, as shown in Figure 5.

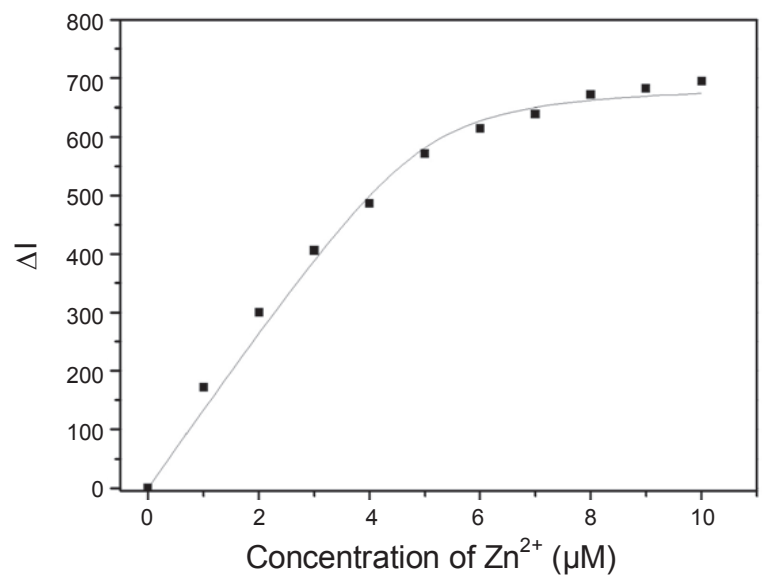

Figure 5. Emission spectra and titration curve of Cp1-b (5 $\mu \mathrm{M})$ in $10 \mathrm{mM}$ HEPES buffer solution (pH 7.4). 
Table 2. Dissociation constants of the peptide sensors for specific metal ions

\begin{tabular}{|c|c|c|c|}
\hline Name & Sequences & Metal Ion & $\begin{array}{c}\mathrm{K}_{\mathrm{d}} \text { Value }(\mathrm{M}) \\
\qquad\left(\mathrm{R}_{2}\right)\end{array}$ \\
\hline Cp1 & Dan-CPGHE-NH ${ }_{2}$ & $\mathrm{Zn}$ (II) & $\begin{array}{c}3.71 \times 10^{-7} \\
(0.97322)\end{array}$ \\
\hline Cp1-a & Dan-HPGCE-NH ${ }_{2}$ & $\mathrm{Zn}$ (II) & $\begin{array}{c}4.24 \times 10^{-7} \\
(0.98528)\end{array}$ \\
\hline Cp1-b & Dan-CHPGH-NH ${ }_{2}$ & $\mathrm{Zn}$ (II) & $\begin{array}{l}1.58 \times 10^{-7} \\
(0.99217)\end{array}$ \\
\hline Cp1-c & Dan-EPGCH-NH ${ }_{2}$ & $\mathrm{Zn}$ (II) & $\begin{array}{c}1.67 \times 10^{-6} \\
(0.82611)\end{array}$ \\
\hline Cp1-d & Dan-HHPGE-NH ${ }_{2}$ & $\mathrm{Zn}$ (II) & $\begin{array}{l}6.66 \times 10^{-7} \\
(0.97997)\end{array}$ \\
\hline \multirow[t]{2}{*}{ Cp1-e } & Dan-CCHPGE-NH ${ }_{2}$ & Cd (II) & $\begin{array}{c}2.38 \times 10^{-9} \\
(0.98947)\end{array}$ \\
\hline & & $\mathrm{Zn}$ (II) & $\begin{array}{c}4.98 \times 10^{-8} \\
(0.96998)\end{array}$ \\
\hline
\end{tabular}

Table 2 summaries the dissociation constants of the peptide sensors for $\mathrm{Zn}^{2+}$. The $\mathrm{K}_{\mathrm{d}}$ values indicated the binding affinities of the peptide sensors in $100 \%$ aqueous solutions were more potent than those of the other chemical sensors for $\mathrm{Zn}^{2+} \cdot{ }^{13}$ The binding affinity of the peptides was potent enough to detect micromolar range of $\mathrm{Zn}^{2+}$ in aqueous solution. Even though the peptides (Cp1, Cp1-a, Cp1-b, Cp1-c and Cp1-d) had the same amino acid composition, the $\mathrm{K}_{\mathrm{d}}$ values of the peptides were different. The $\mathrm{K}_{\mathrm{d}}$ value of $\mathbf{C p 1 - b}$ for $\mathrm{Zn}^{2+}$ is the lowest among them. The calculated $K_{d}$ value of Cp1-c is the highest and fitting of the titration curve of emission intensity change $v s$ concentration provided poor $\mathrm{R}^{2}$ value. This result indicates that the position of the amino acids as a ligand in the peptide sensors plays an important role in the binding affinity to $\mathrm{Zn}^{2+}$.

Cp1-d shows a great selectivity for $\mathrm{Zn}^{2+}$ over $\mathrm{Cd}^{2+}$. The binding affinity for $\mathrm{Zn}^{2+}$ is comparable to those of the other peptide sensors. This shows a possibility of the development of selective and sensitive peptide sensors for $\mathrm{Zn}^{2+}$ over $\mathrm{Cd}^{2+}$ by changing amino acid sequence. Interestingly, Cp1-e preferentially binds $\mathrm{Cd}^{2+}$ over $\mathrm{Zn}^{2+}$ and has nanomolar affinity $\left(\mathrm{K}_{\mathrm{d}}=24 \mathrm{nM}\right)$ for $\mathrm{Cd}^{2+}$ in aqueous solution. Thus, the peptide has a great potential for monitoring the trace amounts of $\mathrm{Cd}^{2+}$ in aqueous solution due to its potent binding affinity for $\mathrm{Cd}^{2+}$. Very low $\mathrm{K}_{\mathrm{d}}$ values of Cp1-e for $\mathrm{Cd}^{2+}$ and $\mathrm{Zn}^{2+}$ suggest that the increase of metal binding amino acids (Cys, His, and Glu) in the peptide moiety promotes a higher metal binding affinity but decrease selectivity for specific metal ions.

In conclusion, we show that the selectivity and sensitivity of the metallopeptide sensors to specific heavy and transition metal ions can be tuned by changing amino acid sequence. We successfully synthesize $\mathrm{Zn}^{2+}$ selective peptide sensor with a potent binding affinity $\left(\mathrm{K}_{\mathrm{d}}=670 \mathrm{nM}\right)$ and $\mathrm{Cd}^{2+}$ selective and sensitive peptide sensor with a potent binding affinity $\left(\mathrm{K}_{\mathrm{d}}=\right.$ $24 \mathrm{nM})$.

\section{Experimental}

Reagents. Fmoc protected amino acids, $N, N^{\prime}$-diisopropylcarbodiimide, 1-hydroxybenzotriazole, and Rink Amide MBHA resin were from Novabiochem. Other reagents for peptide synthesis including trifluoroacetic acid (TFA), tri-isopropylsilane (TIS), dansyl chloride, triethylamine, diethyl ether, dimethyl sulfoxide (DMSO), $N, N$-dimethylformamide (DMF) and piperidine were purchased from Aldrich.

Peptide synthesis. The peptides were synthesized using Fmoc-chemistry by solid phase peptide synthesis with Fmoc chemistry. ${ }^{8}$ The coupling of dansyl chloride was performed by applying the following procedure. To the resin bound peptide (65 mg, $0.05 \mathrm{mmol}$ ), dansyl chloride ( $40 \mathrm{mg}, 0.15 \mathrm{mmol}, 3$ equiv) in DMF ( $3 \mathrm{~mL})$ containing triethylamine $(20 \mu \mathrm{L}, 0.15 \mathrm{mmol}$, 3 equiv) were added and kept for 2 hour at room temperature. Deprotection and cleavage was achieved by treatment with a mixture of TFA/TIS $/ \mathrm{H}_{2} \mathrm{O}$ (9.5:0.25:0.25, v/v/v) at room temperature for 3 - $4 \mathrm{~h}$. After cleavage of the product from resin, the peptides were purified by preparative-HPLC using a water $(0.1 \%$ TFA $)$ /acetonitrile $(0.1 \%$ TFA) gradient (5 - 50\% acetonitrile over $45 \mathrm{~min}$ ). The peptide mass were characterized by ESI mass spectrometer (Platform II, Micromass, Manchester, UK). The homogeneity ( $>95 \%$ ) of the compound was confirmed by analytical HPLC on a $\mathrm{C}_{18}$ column.

General fluorescence measurements. Fluorescence emission spectrum of a peptide probe in a $10 \mathrm{~mm}$ path length quartz cuvette was measured in $10 \mathrm{mM}$ HEPES buffer solution $(\mathrm{pH}=$ 7.4) using a Perkin-Elmer luminescence spectrophotometer (model LS 55). Emission spectra (350-650 nm) of the peptide probes $(5 \mu \mathrm{M})$ in the presence of various metal ions $\left(\mathrm{Hg}^{2+}\right.$, $\mathrm{Ca}^{2+}, \mathrm{Cd}^{2+}, \mathrm{Co}^{2+}, \mathrm{Pb}^{2+}, \mathrm{Ag}^{+}, \mathrm{Mg}^{2+}, \mathrm{Cu}^{2+}, \mathrm{Mn}^{2+}, \mathrm{Ni}^{2+}$, and $\mathrm{Zn}^{2+}$ as perchlorate anion; and $\mathrm{Na}^{+}, \mathrm{Al}^{3+}$, and $\mathrm{K}^{+}$, as chloride anion) were measured by excitation with $330 \mathrm{~nm}$ for chelation enhanced fluorescence measurement. The slit size for excitation and emission was $5 \mathrm{~nm}$, respectively. The concentration of peptide probe was confirmed by UV absorbance at $330 \mathrm{~nm}$ for dansyl group.

Determination of binding stoichiometry and binding constant. The binding stoichiometry of peptides with metal ions was determined by using Job's plot. ${ }^{14}$ A series of solutions with varying mole fraction of metal ions were prepared by maintaining the total peptide and metal ion concentration constant $(2.5 \mu \mathrm{M})$. The fluorescence emission was measured for each sample by exciting at $330 \mathrm{~nm}$ and spectra were measured from 350 to $650 \mathrm{~nm}$. The fitting data were acquired by plotting a straight line through the maximum or minimum emission intensity in the titration curve and were plotted against the mole fraction of the metal ion versus emission intensity.

The dissociation constant was calculated based on the titration curve of the peptide with metal ion. The fluorescence signal, $\mathrm{F}$, is related to the equilibrium concentration of the complex (HL) between peptide (H) and metal ion (L) by the following expression:

$$
\begin{aligned}
& \mathrm{F}=\mathrm{F}_{\mathrm{o}}+\Delta \mathrm{F} *[\mathrm{HL}] \\
& {[\mathrm{HL}]=0.5 \times\left[\mathrm{K}_{\mathrm{D}}+\mathrm{L}_{\mathrm{T}}+\mathrm{H}_{\mathrm{T}}-\left\{\left(-\mathrm{K}_{\mathrm{D}}-\mathrm{L}_{\mathrm{T}}-\mathrm{H}_{\mathrm{T}}\right)^{2}-4 \mathrm{~L}_{\mathrm{T}} \mathrm{H}_{\mathrm{T}}\right\}^{1 / 2}\right]}
\end{aligned}
$$

Where $\mathrm{F}_{\mathrm{o}}$ is the fluorescence of the probe only and $\Delta \mathrm{F}$ is the change in fluorescence due to the formation of HL. The dissociation constants were determined by a nonlinear least squares fit of the data with the equation. ${ }^{15}$ 
Acknowledgments. This work was supported by grant of Inha University in Korea. Joung-Min Kim and Bishnu Prasad Joshi were recipients of a BK21 (II) fellowship.

\section{References}

1. (a) Bode, W.; Gomis-Ruth, F. X.; Stockler, W. FEBS Lett. 1993, 331, 134. (b) Vallee, B. L.; Auld, D. S. Biochemistry 1990, 29, 5647. (c) Hay, M.; Richards, J. H.; Lu, Y. Proc. Natl. Acad. Sci. USA 1996, 93, 461. (d) Blindauer, C. A.; Sadler, P. J. Acc. Chem. Res. 2005, 38, 62.

2. (a) Lipscomb, W. N.; Strater, N. Chem. Rev. 1996, 96, 2375. (b) Eren, E.; Gonzalez-Guerrero.; Kaufman, B. M.; Arguello, J. M. Biochemistry 2007, 46, 7754. (c) Banci, L.; Bertini, I.; Ciofi-Baffoni, S.; Finney, L. A.; Outten, C. E.; O'Halloran, T. V. J. Mol. Biol. 2002, 323, 883. (d) Liu, J.; Stemmler, A. J.; Fatima, J.; Mitra, B. Biochemistry 2005, 44, 5159 .

3. Joshi, B. P.; Cho, W. M.; Kim, J.; Yoon, J.; Lee, K. H. Bioorg. Med. Chem. Lett. 2007, 23, 6425.

4. Joshi, B. P.; Lee, K. H. Bioorg. Med. Chem. 2008, 16, 8501.

5. Joshi, B. P.; Park, J. W.; Lee, W. I.; Lee, K. H. Talanta 2009, 78, 903.

6. (a) Fisk, J. D.; Gellman, S. H. J. Am. Chem. Soc. 2001, 123, 343. (b) Haque, T. S.; Gellman, S. H. J. Am. Chem. Soc. 1997, 119, 2303.

7. (a) Wang, Z.; Lee, J. H.; Lu, Y. Chem. Commun. 2008, 6005. (b) Li, H.; Li, Y.; Dang, Y.; Ma, L.; Wu, Y.; Hou, G.; Wu, L. Chem. Commun. 2009, 4453. (c) White, B. R.; Liljestrand, H. M.; Holcombe, J. A. Analyst 2008, 133, 65. (d) Leray, I.; Lefevre, J.; Delouis, J.; Delaire, J.; Valeur, B. Chem. Eur. J. 2001, 7, 4590. (e) Balzani, V.; Ceroni, P.; Gestermann, S.; Kauffmann, C.; Gorka M.; Vogtle, F. Chem. Commun. 2000, 853. (f) Vogtle, F.; Gestermann, S.; Kauffmann, C.; Ceroni, P.; Vicinelli, V.; Balzani, V. J. Am. Chem. Soc. 2000, 122, 10398. (g) Deo, S.; Godwin, H. A. J. Am. Chem. Soc. 2000, 122, 174. (h) Aoki, S.; Kawatani, H.; Goto, T.; Kimura, E.; Shiro, M. J. Am. Chem. Soc. 2001, 123, 1123. (i)
Haugland, R. P. Molecular Probes, 6th ed.; Eugene: OR, 1996. (j) Kavallieratos, K.; Rosenberg, J. M.; Chen, W.; Ren, T. J. Am. Chem. Soc. 2005, 127, 6514. (k) Zheng, Y.; Gattas-Asfura, K. M.; Konka, V.; Leblanc, R. M. Chem. Commun. 2002, 2350. (1) Métivier, R.; Leray, I.; Valeur, B. Photochem. Photobiol. Sci. 2004, 3, 374. (m) Metivier, R.; Leray I.; Valeur, B. Chem. Eur. J. 2004, 10,4480 .

8. Fields, G. B.; Nobel, R. L. Int. J. Pept. Protein Res. 1990, 35, 161.

9. (a) Kimura, E.; Koike, T. Chem. Soc. Rev. 1998, 27, 179. (b) Walkup, G. K.; Imperiali, B. J. Am. Chem. Soc. 1996, 118, 3053.

10. Harford C.; Sarkar, B. Acc. Chem. Res. 1997, 30, 123.

11. (a) Varnes, A. V.; Dodson, R. B.; Whery, E. L. J. Am. Chem. Soc. 1972, 94, 946-950. (b) Mu, H.; Gong, Rui.; Ma, Q.; Sun, Y.; Fu, E. Tetrahedron Lett. 2007, 48, 5525-5529. (d) Goswami, S.; Chakraborty, R. Tetrahedron Lett. 2009, 50, 2911-2914.

12. (a) Falchuk, K. H. Mol. Cell. Biochem. 1998, 188, 41. (b) Zalewski, P. D.; Forbes, I. J.; Betts, W. H. Biochem. J. 1993, 296, 403. (c) Maret, W.; Jacob, C.; Vallee, B. L.; Fischer, E. H. Proc. Natl. Acad. Sci. USA 1999, 96, 1936. (d) Bush, A. I.; Pattingel, W. H.; Multhaup, G.; Paradis, M. D.; Vonsattel, J. P.; Gusella, J. F.; Beyreuther, K.; Masters, C. L.; Tanzi, R. E. Science 1994, 265, 1464.

13. (a) Ajayaghosh, A.; Carol, P.; Sreejith, S. J. Am. Chem. Soc. 2004, 127, 14962, and reference therein. (b) Frederickson, C. J.; Bush, A. I. Biometals 2001, 14, 353. (c) Nolan, E. M.; Jaworski, J.; Okamoto, K.; Hayashi, Y.; Sheng, M.; Lippard, S. J. J. Am. Chem. Soc. 2005, 127,16812. (d) Hanaoka, K.; Kikuchi, K.; Kojima, H.; Urano, Y.; Nagano, T. J. Am. Chem. Soc. 2004, 126, 12470. (e) Xu, Z.; Baek, K.-H.; Kim, H. N.; Cui, J.; Qian, X.; Spring, D. R.; Shin, I.; Yoon, J. J. Am. Chem. Soc. 2010, 132, 601.(f) Chen, X.; Zhou, W. Y.; Peng, W. X.; Yoon, J. Chem. Soc. Rev. 2010, 39, 1996.

14. (a) Lakowicz, J. R. Principles of Fluorescence Spectroscopy; Kluwer Academic Plenum: New York, 1999. (b) Likussar, W.; Boltz, D. F. Anal. Chem. 1971, 43, 1265.

15. Reddi, A. R.; Guzman, T. R.; Breece, R. M.; Tierney, D. L.; Gibney, B. R. J. Am. Chem. Soc. 2007, 129, 12815. 